\title{
ANALISIS DAYA SAING KOMODITI EKSPOR UNGGULAN INDONESIA DI PASAR INTERNASIONAL
}

\author{
Farid Ustriaji \\ Fakultas Ekonomi dan Bisnis \\ PT. Bank Mandiri Tbk. \\ fariedustriaji@gmail.com
}

\begin{abstract}
Research aimed to investigate the growth, contribution, and also the competitiveness of excellent commodity exports comprising textile and textilebased products, electronics, rubber, rubber-palmed products and oil-palmed products, forest products, footwear, automotive, shrimp, cocoa, and coffee. In fact, this research revealed that: Some of those commodity exports exhibited the significant increase: The oil-palmed products were the most greatly contributive amongst commodity exports of which accumulation achieved first and total of exports reached during 2010-2014: The RCA formulation of oil-palmed products, footwear, cacao, coffee, rubber, and textile in 2010-2014 commodity exports had excellent competitiveness throughout international world.
\end{abstract}

Keywords: Competitiveness, Growth, Contribution, Exports

\begin{abstract}
ABSTRAK
Tujuan penelitian adalah untuk mengetahui tentang pertumbuhan, kontribusi serta daya saing dari komoditi unggulan Indonesia yang terdiri dari tekstil dan produk tekstil (TPT), elektronik, karet dan produk karet,sawit dan produk sawit, produk hasil hutan, alas kaki,otomotif, udang, kakao, dan kopi. Hasil penelitian menunjukkan: Pada komoditi unggulan Indonesia dari beberapa komoditi tersebut mengalami kenaikan pertumbuhan yang cukup signifikan. Penyumbang kontribusi terbesar dari komoditi unggulan tersebut ada pada komoditi sawit yang mencapai peringkat pertama dengan nilai total ekspor tahun 2010-2014. Dari perhitungan RCA menunjukan bahwa industri sawit, hasil hutan, alas kaki, kakao, kopi, karet, dan tekstil pada tahun 2010-2014 memiliki daya saing diatas daya saing rata-rata dunia.
\end{abstract}

Kata Kunci: daya saing, pertumbuhan, kontribusi, ekspor.

\section{PENDAHULUAN}

Pasca revolusi di Inggris abad

19 telah mendorong pusut pusat industri baru di berbagai penjuru dunia yang kemudian di sebut sebagai "dunia peradaban baru" atau "region of recent settlement" pada peradaban dunia baru tersebut sangat di pengaruhi oleh aktivitas ekspor dan impor, terutama ekspor. Negara maju seperti Inggris, Perancis, Jerman dan negara maju lainya mengalami pertumbuhan ekonomi yang pesat karena pertumbuhan ekonominya berstandart pada aktivitas perdagangan terutama ekspor. Hal ini menunjukan bahwa ekspor merupakan kegiatan 
perdagagan internasional yang telah menjadi mesin pertumbuhan bagi negara berkembang, dengan kegiatan ekspor negara berkembang dapat meningkatkan devisa sehingga akan meningkatkan kaekayaan atau pendapatan negara, secara tidak langsung juga dapat meningkatkan pendapatkan perkapita (the ekspor let growh hypothesis).(Soekarwati;1991)

Pada perdagangan bebas negara yang memiliki daya saing paling tinggi adalah sebagai negara pemenang, yang artinya negara tersebut juga menikmati keuntungan yang optimal dari perdagangan bebas, sedangkan untuk negara yang kurang atau gagal dalam melakukan daya saing akan sulit memiliki keuntungan dalam perdagangan bebas dan hanya cenderung menjadi pasar bagi Negara lain saja.

Ekspor dapat diartikan sebagai kegiatan yang menyangkut produksi barang dan jasa yang diproduksi disuatu negara untuk dikonsumsikan di luar batas negara tersebut. Lebih jelasnya menambahkan bahwa ekspor merupakan kelebihan produksi dalam negeri yang kemudian kelebihan produksi tersebut dipasarkan di luar negeri. Pengertian ekspor menurut Keputusan Menteri Perindustrian dan Perdagangan Nomor 182/MPP/Kep/4/1998 tentang Ketentuan Umum di Bidang Ekspor, menyatakan bahwa ekspor adalah kegiatan mengeluarkan barang dan jasa dari daerah kepabeanan suatu negara. Adapun daerah kepabeanan sendiri didefinisikan sebagai wilayah Republik Indonesia yang meliputi wilayah darat, perairan dan ruang udara diatasnya, serta tempat-tempat tertentu di zona ekonomi eksklusif dan landas kontinen yang didalamnya berlaku Undang-Undang No.10 tahun 1995 tentang Kepabeanan.(Hirman Hamidi,2007)

$$
\text { Daya saing juga }
$$
mengindikasikan terjadinya penguatan perekonomian domestik dengan orientasi dan daya saing global. Secara makro, teori globalisasi ekonomi dapat diartikan sebagai sebuah teori yang didasarkan atas asumsi perdagangan bebas/pasar bebas di seluruh dunia, tanpa adanya hambatan baik dalam bentuk tarif atau non tarif. Namun secara mikro, globalisasi ekonomi dapat diartikan sebagai sebuah inisiatif bisnis yang didasarkan atas kepercayaan bahwa 
dunia telah menjadi sedemikian homogen, seiring dengan makin mengaburnya perbedaan nyata antar pasar domestik. Tentang kerja sama regional. mengemukakan bahwa kerja sama ekonomi dan keuangan, khususnya di bidang perdagangan internasional, saat ini mengarah pada pembentukan kerja sama guna mewujudkan integrasi ekonomi dan keuangan secara regional. (Ade Komarudin,2015). Daya saing diidentikkan dengan produktivitas dimana tingkat output yang dihasilkan untuk setiap unit input yang digunakan. (Michael E porter. 2007). daya saing merupakan kemampuan suatu produsen untuk memproduksi suatu komoditi dengan biaya yang cukup rendah sehingga harga-harga yang terjadi di pasar internasional kegiatan produksi tersebut menguntungkan.

(Febriyanthi. 2008). Pertumbuhan ekonomi merupakan masalah perekonomian jangka panjang dan menjadi kenyataan yang selalu dialami oleh suatu bangsa. Ditinjau dari sudut ekonomi, perkembangan ekonomi menimbukan dua efek penting, yaitu kemakmuran atau taraf hidup masyarakat meningkat dan penciptaan kesempatan kerja baru karena semakin bertambahnya jumlah penduduk. (Ratna Kurnia.2012). Keunggulan kompetitif adalah keunggulan yang dimiliki oleh suatu Negara atau bangsa untuk dapat bersaing di pasar internasional. dalam persaingan global saat ini suatu bangsa atau Negara memiliki competitive advantage of nation dapat bersaing di pasar internasional bila memiliki empat faktor penentu dan dua faktor pendukung, empat faktor utama yang menentukan daya saing suatu komoditi adalah kondisi faktor (factor condition), kondisi permintaan (demand condition), industry terkait dan industri pendukung yang kompetitif (firm strategy,structure, and rivalry). Ada dua faktor yang mempengaruhi interaksi antara keempat faktor tersebut yaitu faktor kesepatan (change event) dan faktor pemerintahan (government). Secara bersama-sama faktor ini membentuk sistem dalam peningkatan keunggulan daya saing tersebut Porters Diamon's Theory.(Hendra Rakhmawan,2009) Hukum keunggulan komparatif pertama kali 
dijelaskan dalam buku yang diterbitkan oleh David Ricardo yang berjudul Principles of Political Economy and Taxation pada tahun 1817. Menurut tingkat keunggulan komparatif tersebut meskipun suatu Negara mengalami kerugian atau ketidak unggulan absolut untuk memproduksi dua komoditi jika di bandingkan dengan negara lain, namun perdagangan yang masih menguntungkan masih dapat berlangsung. Negara Indonesia yang baru baru ini yang mengalami peningkatan devisa karena mengalami peningkatan dari kegiatan perdagangan luar negeri terutama ekspor, dan setelah diamati Indonesia memiliki 10 komoditi ekspor unggulan yang sangat memberikan potensi peningkatan devisa negara yang diharapkan 10 komodi unggulan tersebut memiliki daya saing yang kuat dari negara lainya. 10 komoditii unggulan tersebut di klarifikasikan oleh Disperindag diantaranya adalah tekstil dan produk tekstil (TPT), elektronik, karet dan produk karet, sawit dan produk sawit, produk hasil hutan, alas kaki, otomotif, udang, kakao, dan kopi.
TPT memiliki pasar utama ekspor yang masih prospektif seperti Amerika, Eropa, Timur Tengah, dan Asean. Sedangkan komoditi alas kaki seperti sepatu ditargetkan meningkat di atas 20 persen karena adanya relokasi 2 pabrik di Purwakarta dan Tangerang serta turnover Indonesia lebih rendah dibandingkan China. Untuk sektor otomotif di targetkan meningkat 10 persen karena industry otomotif terus tumbuh. Kertas juga di targetkan terus tumbuh karena adanya pencabutan tariff bea masuk anti dumping di Korea Selatan, Indonesia menguasai 20-25 persen di pangsa pasar Korea Selatan. Sedangkan biji kakao meningkat 22 persen dan kakao olahan meningkat 61 persen. Meningkatnya target ekspor kakao olahan disebabkan oleh meningkatnya kapasitas produksi kakao olahan dari 180 ton meningkat hingga 280 ton, dan di harapkan pada setiap komoditi unggulan di Indonesia memiliki daya saing yang kuat di era perdagangan luar negeri, sehingga dapat meningkatkan pendapatan negara dan dapat bersaing keras di kancah pasar internasional. Tujuan dari penelitian ini adalah: 1) untuk mengetahui 
tingkat pertumbuhan 10 komoditi unggulan Indonesia di pasar internasional. 2) untuk mengetahui seberapa besar kontribusi yang di berikan dari 10 macam komoditi unggulan tersebut. 3) untuk mengetahui tingkat daya saing dari 10 komoditi unggulan Indonesia di pasar internasional.

\section{METODE PENELITIAN}

Lokasi penelitian ini adalah pada wilayah Indonesia yang memproduksi dari 10 kriteria komoditi unggulan indonesia. Jenis penelitian ini adalah penelitian kuantitatif yaitu jenis penelitian yang bertujuan untuk menjelaskan sesuatu dan mendeskripsikan hasil analisis yang telah di hitung. Data yang dianalisis dalam penelitian ini adalah data sekunder yang bersifat kuantitatif yang di kutip dari data internasional yaitu ICT

(International Trade Center) dalam lima tahun pada tahun 2010-2014.

\section{Analisis Data}

Analisis Pertumbuhan

Adapun rumus analisis pertumbuhan yang digunakan sebagai berikut:

$$
\Delta X=\frac{X_{t}-X_{(t-1)}}{X_{(t-1)}} \times 100 \%
$$

Dimana

$\Delta X=$ Pertumbuhan ekspor

$\mathrm{Xt}=$ Ekspor $\mathrm{h} /$ priode $\mathrm{t}$

$\mathrm{X}(\mathrm{t}-1)=$ Ekspor $\mathrm{h}$ tahun sebelumnya. Analisis Kontribusi

Analisis kontribusi bertujuan untuk mengetahui seberapa besar perananan ekspor komoditi i terhadap total 10 ekspor unggulan di Indonesia, yaitu dengan menggunakan rumus:

$\mathbf{X} \mathbf{i}=\frac{\sum \text { komodit } i}{\sum \text { Total ekspor unggulan }} \times \mathbf{1 0 0} \%$

RCA (Revealed Comparative

\section{Advantage)}

Tingkat daya saing komoditas ekspor suatu negara atau industri dapat dianalisis dengan berbagai macam metode atau diukur dengan sejumlah indikator. Salah satu diantaranya adalah Revealed Comparative Advantage (RCA).

$C=\frac{X_{i j} / X_{i s}}{X_{j} / X_{s}}$

$\mathrm{C}=$ Angka RCA

$X_{i j}=$ nilai ekspor komoditi $i$

Indonesia tahun $t$

$X_{i s}=$ nilai ekspor seluruh komoditi Indonesia tahun $t$

$W_{j}=$ nilai ekspor komoditi $i$ dunia tahun $t$ 
$W_{s}=$ nilai ekspor komoditi dunia tahun $t$

Jika nilai indeks RCA dari suatu negara untuk komoditas tertentu lebih besar dari 1, berarti negara yang bersangkutan mempunyai keunggulan komparatif di atas rata-rata dunia dalam komoditas tersebut. Sebaliknya, bila lebih kecil dari 1 berarti keunggulan komparatifnya untuk komoditas tersebut rendah atau di bawah ratarata dunia. (Haris Munandar dan Faisal Basri,2010)

\section{PEMBAHASAN}

Pertumbuhan komoditi tekstil dan produk tekstil dapat di lihat dari tahun 2010-2014 mengalami fluktuasi nilai ekspor. Dimana pertumbuhan ekspor tertinggi pada tahun 2011 dengan persentase sebesar 17\%, menurun di tahun 2012 dengan persentase $-5 \%$, mengalami kenaikan di tahun 2013 dengan persentase $3 \%$, mengalami penurunan terendah di tahun 2014 dengan persentase $1 \%$. Pertumbuhan komoditi elektronik dapat di lihat dari tahun 2010-2014 mengalami peningkatan yang signifikan pada nilai ekspor. Pertumbuhan komoditi elektronik pada tahun 2011 sebesar $13 \%$ yang kemudian meningkat menjadi $16 \%$ pada tahun 2012 , dan turun drastis menjadi $0 \%$ di tahun 2013 yang meningkat kembali sebesar 4\% di tahun 2014. Pertumbuhan komoditi karet dan produk karet dapat di lihat dari tahun 2010-2014 mengalami fluktuasi pada nilai ekspor. Dimana pertumbuhan pada tahun 2011 sebesar 46\%, turun di tahun 2012 sebesar -23\%, yang kemudian meningkat menjadi $-8 \%$, dan menurun kembali di tahun 2014 sebesar $18 \%$. Pertumbuhan komoditi Sawit dapat di lihat dari tahun 20102014 mengalami fluktuatif pada nilai ekspor. Yang pada tahun 2011 pertumbuhan sawit sebesar $28 \%$, menurun sebesar 2\% di tahun 2012, menurun kembali mejadi $-10 \%$ di tahun 2013, dan meningkat kembali di tahun 2014 sebesar 10\%. Pertumbuhan komoditi Produk Hasil Hutan dapat di lihat dari tahun 20102014 mengalami fluktuasi pada nilai ekspor. Pertumbuhan produk hasil hutan pada tahun 2011 sebesar 6\%, yang turun menjadi $-2 \%$ pada tahun 2012, meningkat kembali di tahun 2013 sebesar 3\%, dan pada tahun 2014 sebesar 3\%. Pertumbuhan 
komoditi Alas Kaki dapat di lihat dari tahun 2010-2014 mengalami peningkatan nilai ekspor. Pertumbuhan alas kaki di tahun 2011 sebesar 32\%, yang mengalami penurunan menjadi $7 \%$ di tahun 2012, meningkat di tahun 2013 sebesar 10\%, dan pada tahun 2014 menurun sebesar 6\%. Pertumbuhan komoditi Otomotif dapat di lihat dari tahun 2010-2012 mengalami fluktuasi pada nilai ekspor. Pertumbuhan otomotif pada tahun 2011 sebesar 15\%, meningkat pada tahun 2012 sebesar 24\%, menurun di tahun 2013 sebesar $-4 \%$, dan meningkat kembali untuk pertumbuhan di tahun 2014 sebesar 6\%. Pertumbuhan komoditi udang dapat di lihat dari tahun 2010-2012 cenderung mengalami fluktuasi pada nilai ekspor. Pertumbuhan udang pada tahun 2011 sebesar 25\%, yang mengalami tenurunan pertumbuhan yang sangat drastis di tahun 2012 sebesar $100 \%$, meningkat di tahun 2013 sebesar $-1 \%$, dan meningkat kembali di tahun 2014 sebesar 7\% untuk pertumbuhan udang. Pertumbuhan komoditi kakao dapat di lihat dari tahun 2010-2013 cenderung mengalami fluktuasi pada nilai ekspor. Pertumbuhan kakao pada tahun 2011 sebesar 18\%, menurun di tahun 2012 sebesar 22\%, mengalami peningkatan di tahun 2013 sebesar 9\%, dan penurunan pertumbuhan sebesar $8 \%$ di tahun 2014. Pertumbuhan komoditi kopi dapat di lihat dari tahun 2010-2014 mengalami fluktuatif pada nilai ekspor. Pertumbuhan kopi pada tahun 2011 sebesar 27\%, yang mengalami menurunan sebesar $21 \%$ pada tahun 2012, mengalami penurunan pertumbuhan kembali di tahun 2013 sebesar $-6 \%$, dan terus mengalami penurunan sebesar $-11 \%$ pada tahun 2014.

\section{Analisis Kontribusi}

Berikut adalah nilai kontribusi yang di berikan dari 10 komoditi unggulan Indonesia dari tahun 20102014, dari data di atas dapat di lihat hasil persentase kontribusi dan ratarata setiap komoditi dari tahun 20102014. dari masing-masing komoditi, pada tingkat pertama adalah komoditi sawit yang rata-rata selama 2010-2014 mencapai 28\%, urutan kedua komoditi karet dengan ratarata $21 \%$, urutan ketiga komoditi Produk Hasil Hutan dengan rata-rata sebesar $15 \%$ dengan total ekspor 
US\$ 45.742.559, urutan keempat adalah komoditi tekstil dan produk tekstil dengan rata-rata $15 \%$ dengan total ekspor US\$ 44.126.897, urutan kelima pada komoditi otomotif ratarata sebesar 9\% dengan total ekspor US\$ 26.615.151, urutan keenam pada komoditi Alas Kaki rata-rata sebesar 6\% dengan total ekspor US\$ 17.297.227, urutan ketujuh pada komoditi Kakao rata-rata sebesar $2 \%$ dengan total ekspor US\$6.438.385, urutan ke delapan pada komoditi kopi rata-rata sebesar 2\% dengan total ekspor US\$ 5.314.154, urutan kesembilan pada komoditi elektronik rata-rata sebesar 1\% dengan total ekspor US\$ 3.449.909, dan urutan kesepuluh pada komoditi Udang dengan rata-rata $1 \%$ dan total ekspor sebesar US\$ 1.813.201.

Tabel 1. Persentase Kontribusi Ekspor 10 Komoditi Unggulan Indonesia

\begin{tabular}{lcccccc}
\hline \multirow{2}{*}{ Komoditi } & \multicolumn{5}{c}{ Tahun (\%) } & \multirow{2}{*}{ Rata-Rata } \\
\cline { 2 - 6 } Sawit & 2010 & 2011 & 2012 & 2013 & 2014 & \\
\hline Karet dan Produk Karet & $26 \%$ & $27 \%$ & $29 \%$ & $27 \%$ & $30 \%$ & $28 \%$ \\
\hline Produk Hasil Hutan & $17 \%$ & $14 \%$ & $15 \%$ & $16 \%$ & $16 \%$ & $16 \%$ \\
\hline Tekstil dan Produk Tekstil & $15 \%$ & $14 \%$ & $14 \%$ & $15 \%$ & $15 \%$ & $15 \%$ \\
\hline Otomotif & $8 \%$ & $7 \%$ & $10 \%$ & $10 \%$ & $10 \%$ & $9 \%$ \\
\hline Alas Kaki & $5 \%$ & $5 \%$ & $6 \%$ & $7 \%$ & $7 \%$ & $6 \%$ \\
\hline Kakao & $3 \%$ & $2 \%$ & $2 \%$ & $2 \%$ & $2 \%$ & $2 \%$ \\
\hline Kopi & $2 \%$ & $2 \%$ & $2 \%$ & $2 \%$ & $2 \%$ & $2 \%$ \\
\hline Udang & $2 \%$ & $2 \%$ & $0 \%$ & $0 \%$ & $0 \%$ & $1 \%$ \\
\hline Elektronik & $1 \%$ & $1 \%$ & $1 \%$ & $1 \%$ & $1 \%$ & $1 \%$
\end{tabular}

Sumber: ICT, data sekunder diolah

\section{Analisis RCA}

Dari perhitungan RCA dapat menunjukkan bahwa industri tekstil dan produk tekstil pada tahun 20102013 (RCA>1) artinya ekspor tersebut memiliki daya saing diatas daya saing rata-rata dunia. Daya saing tertinggi pada tahun 2010 dan 2011 dengan nilai 1,44. Namun komoditi tekstil dan produk tekstil 2010-2014 memiliki daya saing. Dari perhitungan RCA dapat menunjukkan bahwa Elektronik pada tahun 2010-2014 $(\mathrm{RCA}<1)$ artinya ekspor tersebut tidak memiliki daya saing dibawah daya saing rata-rata dunia. Rata-rata daya saing elektronik hanya 0,13 saja, hal ini 
menujukan bahwa komoditi elektronik memiliki daya saing yang lemah. Dari perhitungan RCA dapat menunjukkan bahwa industri Karet dan Produk Karet pada tahun 20102013 (RCA>1) artinya ekspor tersebut memiliki daya saing diatas daya saing rata-rata dunia. Daya saing tertinggi pada tahun 2011 dengan nilai 1.89. Dan pada tahun 2010-2014 komoditi karet dan produk karet memiliki daya saing di pasar internasional. Dari perhitungan RCA dapat menunjukkan bahwa industri Sawit pada tahun 2010-2014 $(\mathrm{RCA}>1)$ artinya ekspor tersebut memiliki daya saing diatas daya saing rata-rata dunia. Daya saing tertinggi pada tahun 2010 dengan nilai 54,28. Sawit memiliki daya saing yang kuat dari 10 komoditi tersebut. Dari perhitungan RCA dapat menunjukkan bahwa industri Produk Hasil Hutan pada tahun 2010-2014 (RCA>1) artinya ekspor tersebut memiliki daya saing diatas daya saing rata-rata dunia. Daya saing tertinggi pada tahun 2014 dengan nilai 2.84. Dari perhitungan RCA dapat menunjukkan bahwa industri Alas Kaki pada tahun 20102014 (RCA>1) artinya ekspor tersebut memiliki daya saing diatas daya saing rata-rata dunia. Daya saing tertinggi pada tahun 2013 dan 2014 dengan nilai RCA 3,14. Dari perhitungan RCA dapat menunjukkan bahwa Otomotif pada tahun 2010-2014 $(\mathrm{RCA}<1)$ artinya ekspor tersebut tidak memiliki daya saing dibawah daya saing rata-rata dunia. Komoditi Otomotif Indonesia tidak memiliki daya saing di pasar Internasional. Dari perhitungan RCA dapat menunjukkan bahwa industri Udang pada tahun 2010-2011 $(\mathrm{RCA}>1)$ artinya ekspor tersebut memiliki daya saing diatas daya saing rata-rata dunia. Daya saing tertinggi pada tahun 2011 dengan nilai 6,36. Dan di tahun 2012-2014 $(\mathrm{RCA}<1)$ artinya ekspor tesebuttidak memiliki daya saing di pasar internasional. Dari perhitungan RCA dapat menunjukkan bahwa industri Kakao pada tahun 2010-2014 $(\mathrm{RCA}>1)$ artinya ekspor tersebut memiliki daya saing diatas daya saing rata-rata dunia. Daya saing tertinggi pada tahun 2010 dengan nilai 4,11. Dan komoditi kakao memiliki daya saing di pasar internasional. Dari perhitungan RCA dapat menunjukkan bahwa industri 
Analisis Daya Saing Komoditi Ekspor.........(Farid Ustriaji)

Kopi pada tahun 2010-2014

(RCA>1) artinya ekspor tersebut

memiliki daya saing diatas daya

saing rata-rata dunia. Daya saing

tertinggi pada tahun 2013 mencapai

nilai 4,28. Dan pada tahun 2010-

2014 komoditi kopi memuliki daya

saing di pasar internasional. 
Pada komoditi unggulan Indonesia dari beberapa komoditi tersebut mengalami kenaikan pertumbuhan yang cukup signifikan untuk komoditi Alas kaki dan Elektronik, pada komoditi tekstil dan produk tekstil, karet dan produk karet, sawit, produksi hasil hutan, alas, dan kopi mengalami fluktuasi selama tahun 2010-2014, dan cenderung menurun pada kakao, Udang, dan Otomotif. Penyumbang kontribusi terbesar dari 10 komoditi unggulan tersebut ada pada komoditi sawit yang mencapai $28 \%$ dengan nilai total ekspor tahun 2010-2014 sebesar US \$ 81.636.136 dan penyumbang kontribusi terendah pada komoditi udang yang hanya mencapai $1 \%$ dengan nilai total ekspor tahun 2010-2014 sebesar US \$ 1.813.201. Dari perhitungan RCA menunjukan bahwa industri sawit, hasil hutan, alas kaki, kakao, kopi.

\section{PENUTUP}

Pada komoditi unggulan Indonesia dari beberapa komoditi tersebut mengalami kenaikan pertumbuhan yang cukup signifikan untuk komoditi Alas kaki dan Elektronik, pada komoditi tekstil dan produk tekstil, karet dan produk karet, sawit, produksi hasil hutan, alas, dan kopi mengalami fluktuasi selama tahun 2010-2014, dan cenderung menurun pada kakao, Udang, dan Otomotif. Penyumbang kontribusi terbesar dari 10 komoditi unggulan tersebut ada pada komoditi sawit yang mencapai $28 \%$ dengan nilai total ekspor tahun 2010-2014 sebesar US \$ 81.636.136 dan penyumbang kontribusi terendah pada komoditi udang yang hanya mencapai $1 \%$ dengan nilai total ekspor tahun 2010-2014 sebesar US \$ 1.813.201. Dari perhitungan RCA menunjukan bahwa industri sawit, hasil hutan, alas kaki, kakao, kopi, karet, dan tekstil pada tahun 20102014 (RCA>1) artinya ekspor tersebut memiliki daya saing diatas daya saing rata-rata dunia. Nilai tertinggi pada industri sawit pada tahun 2014 dengan nilai RCA 54,28. Sedangkan industri elektronik dan otomotif di tahun 2012-2014 $(\mathrm{RCA}<1)$ artinya ekspor tesebut memiliki daya saing yang lemah. Dan industri udang tahun 2010-2011 $(\mathrm{RCA}>1)$ artinya ekspor tersebut memiliki daya saing diatas daya saing rata-rata dunia. Tahun 2012$20142014(\mathrm{RCA}<1)$ artinya ekspor 
tesebut memiliki daya saing yang lemah.

\section{DAFTAR PUSTAKA}

Basri, Faisal dan Haris Munandar. 2010. Dasar-dasar Ekonomi Internasional: Pengenalan dan Aplikasi Metode Kuantitatif. Jakarta: Kencana.

Febriyanthi. 2008. Pengertian Daya Saing Industri. http://www.google.com/pengerti an-daya-saing-industri.pdf . 3 Januari 2016.

Hamidi, Hirwan, 2007. Daya Saing Tembakau Virginia Lombok di Pasar Ekspor Competitiveness of Lombok Virginia Tobacco in Export Market. Jurnal.
Kania, Ratna, 2012. Analisis Daya Saing Ekspor Lada Indonesia di Pasar Internasioal. Jurnal.

Komarudin, Ade. 2015. Definisi Daya Saing di Dunia Industri. http://www.rmol.co . 6 Januari 2016.

Michael E. Porter. 2007. Strategi Bersaing (competitive strategy). Tangerang : Kharisma Publishing Group.

Rakhmawan, Hendra, 2009. Analisis Daya Saing Komoditi Udang Indonesia di Pasar Internasional. Jurnal

Ricardo, David. 1817. Principles of Political Economy and Taxation.

Soekarwati, 1991. Daya Saing Ekspor The Indonesia di Pasar Teh Dunia. Jurnal 